\title{
SYTUACJA SPOŁECZNO-POLITYCZNA ROMANOWÓW PO REWOLUCJI BOLSZEWICKIE]
}

Ewelina WIĘCKOWSKA

\section{ABSTRACT}

\section{THE SOCIOPOLITICAL SITUATIONS OF ROMANOVS AFTER BOLSHEVIK REVOLUTION}

The main subject of article is sociopolitical situation of Romanovs after the Bolshevik Revolution. The first part is a description of final years of the rule and relations inside the dynasty. The second reverence of the text focus on the problems of White Emigrations and the difficult economic situations of members which survived revolution. The next part tells about organization of the Union of Mladorossi and attempts politicizing the situation of the Romanovs in Europe. The ending is historical reflection. Its aim is to present the political position of the Romanovs in the 21 st century and real chances return to Russia.

\section{KEYWORDS:}


Romanowowie należą dziś do grona najbardziej rozpoznawalnych dynastii na świecie. Powodem ich popularności jest między innymi tragiczny koniec. Wykraczające poza wszelkie ramy etyki morderstwo Mikołaja II i jego rodziny do dziś jest jednym z najczęściej poruszanych tematów historycznych. Po 1918 roku komunistyczne władze Rosji doprowadziły do dosłownego ocenzurowania historii całego rodu. W nieposzanowaniu i zapomnieniu znalazła się dynastyczna spuścizna, a także osoby, które zdołały uniknąć rewolucyjnego wymiaru sprawiedliwości. Przez swoje pochodzenie Romanowowie w latach dwudziestych XX wieku zostali zignorowani przez większość rządów europejskich. Razem ze swoimi koronowanymi przodkami popadli w sidła indoktrynacyjnej rewizji. Większość carów została zdegradowana do pozycji bezmyślnych tyranów. Dopiero upadek Związku Radzieckiego pozwolił bliżej przyjrzeć się dziejom dynastii. Wraz ze zniknięciem sowieckiego giganta otworzyły się strzeżone przez komunistyczne władze archiwa, które przez lata ukrywały dokumenty ujawniające prawdę o życiu Romanowów. Jednakże w centrum zainteresowania naukowców znalazły się wydarzenia z lat 1613-1918. Losy członków dynastii, którzy opuścili w 1919 roku walące się imperium, w dalszym ciągu pozostają na dziejowym marginesie. Fakt ten można uznać za podstawowy bodziec inspiracyjny.

Małe zainteresowanie Romanowami żyjącymi poza granicami Rosji jest główną przyczyną skąpości literatury na ich temat. Dlatego wielką wartość dla artykułu mają źródła epistolarne. Przybliżają one sytuację rodzinną dynastii przed 1917 rokiem i pomagają zrozumieć problemy trapiące krewnych na uchodźstwie. Aspekt ten doskonale porusza publikacja A. Maylunasa i S. Mironenko. Równie ważny pod tym względem jest dziennik wielkiego księcia Aleksandra Michajłowicza². Jego wspomnienia pokazują proces emigracji i pierwsze próby aktywizacji politycznej. W porównaniu do liczby pozycji opisujących życie Romanowów przed rewolucją zasób literatury skupiający się na ich zagranicznej egzystencji jest zadziwiająco mały. Jedynie publikacja Staffana Skotta $^{3}$ porusza aspekt emigracji i życia carskich potomków na obczyźnie. Biorąc pod uwagę ich skomplikowaną wówczas sytuację polityczną, bardzo użyteczna okazuje się także publikacja Orlanda Figesa ${ }^{4}$. Przedstawia ona środowisko kulturalne Białej Emigracji i pomaga zapoznać się z metamorfozą ideologiczną w jej wnętrzu. Ułatwia też analizę położenia politycznego Romanowów i ich statusu w rosyjskich środowiskach.

A. Maylunas, S. Mironenko, Mikotaj II i Aleksandra: nieznana korespondencja, Warszawa 1998.

A.M. Romanow, Bytem Wielkim Księciem (koniec dynastii), Białystok 2004.

S. Skott, Romanowowie wczoraj i dziś, Warszawa 2004.

O. Figes, Taniec Nataszy. Z dziejów kultury rosyjskiej, Warszawa 2011. 
Mord popełniony na rodzinie Mikołaja II doprowadził do wygaśnięcia głównej linii dynastii. $\mathrm{Z}$ tego powodu w XX wieku pojawiło się przekonanie, że ród Romanowów całkowicie wymarł. Pierwszym celem artykułu jest wykazanie na podstawie dostępnej literatury przedmiotu bezpodstawności tego stwierdzenia. Na skutek radzieckiej propagandy Romanowowie przeszli do historii jako ród na wskroś konserwatywny i reakcyjny ${ }^{5}$. Artykuł ma również za zadanie przedstawić metamorfozę aksjologiczną młodszych książąt w przeddzień rewolucji lutowej i opisać ich aktywizację na tle społeczno-politycznym w pierwszej połowie XX wieku. Z racji wykonywania przez nich w tym czasie także innych profesji, został wspomniany wątek ekonomicznej pauperyzacji Romanowów. Ma to na celu ukazać wręcz katastrofalne położenie dynastii i uświadomić znaczenie jej działalności w świecie biznesu i kultury masowej.

Zakres chronologiczny obejmuje lata 1914-1981. Ze względu na duże rozproszenie rodziny Romanowów zasięg terytorialny wykracza poza granice Europy Wschodniej. Wlicza także miejsca ich aktywności społeczno-politycznej. Obok Rosji w centrum zainteresowania znalazły się: Francja, Wielka Brytania, Stany Zjednoczone i Niemcy. Wprowadzenie ma charakter retrospekcji i skupia się na opisie struktury genealogicznej rodu. Służy to łatwiejszej identyfikacji osób, które po 1919 roku znalazły się poza granicami ojczyzny. We wprowadzeniu poświęcono również uwagę sporom dynastycznym na tle sukcesyjnym. Ma to za zadanie przybliżyć sytuację rodzinną dynastii w przeddzień rewolucji lutowej i ułatwić zrozumienie waśni na wygnaniu. Druga część tekstu opisuje początki działalności politycznej Romanowów i środowisko Białej Emigracji. Następny fragment koncentruje się na położeniu ekonomicznym wybranych osób oraz ich sposobach radzenia sobie z rzeczywistością. W dalszym ciągu następuje opis aktywizacji społeczno-politycznej książąt oraz sytuacji życiowej podczas drugiej wojny światowej. Ostatnia część poświęcona jest ambicjonalnym sporom rodzinnym na tle carskiej primogenitury.

W czasach panowania Mikołaja I dynastia uległa procesowi podziału na gałęzie rodowe. Z małżeństwa z Charlottą Hohenzollern car doczekał się siedmiorga dzieci. Najstarszy Aleksander Mikołajewicz często figuruje w literaturze jako uciekający przed terrorystami car oswobodziciel. Po poślubieniu Maksymiliany Wilhelminy Marii von Hessen-Darmstadt na świat przyszło ośmioro dzieci, których potomkowie uciekli z Rosji w 1919 roku.

Przez cały XIX wiek stosunki między Romanowami były bardzo napięte. W czasach Aleksandra III ich stan był tak zły, że stały się pożywką dla dziennikarzy. Pewnego razu jeden z reporterów napisal: „Aleksander wrzeszczy na rodzinę podczas wakacji 


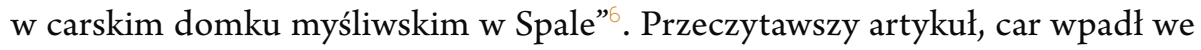
wściekłość, krzycząc na ministra dworu: „Nigdy nie czytałem w gazetach czegoś tak głupiego, niesprawiedliwego i niestosownego, co za bzdurne szczegóły!”’ Przyczyną tego stanu rzeczy była rodzinna ambicja i poczucie niesprawiedliwości na tle sukcesyjnym. Ustalona przez Pawła I w 1797 roku zasada primogenitury dopuszczała do tronu tylko najstarszych synów cara lub jego braci w przypadku braku męskiego potomstwa. Już w czasach Mikołaja I wywołało to żal u krewnych. Przykładem jest wypowiedź brata Aleksandra II, Konstantego: „To niesprawiedliwe, że Sasza został następcą tronu”. Carowie zdawali sobie sprawę z niezadowolenia i chorobliwej ambicji braci. Ocalały z zamachu kolejowego pod Borkami Aleksander III powiedział zgryźliwie o swoim rodzeństwie: „Dzięki Bogu, i ja, i chłopcy żyjemy. Ale Władimir będzie zawiedziony!”. Zdając sobie sprawę $\mathrm{z}$ frustracji krewnych, car w 1886 roku zawęził grono spadkobierców do synów i bezpośrednich wnuków Aleksandra II. Zachowali oni tytuły wielkoksiążęce. Osoby genealogicznie oddalone od cesarza zdegradował do pozycji książąt cesarskiej krwi. Dlatego w czasach Mikołaja II primogenitura objęła cztery gałęzie rodowe. Zaraz za carewiczem, dziedzicem, był brat cara, wielki książę Michał Aleksandrowicz. Następny w kolejce stał potomek wielkiego księcia Władimira, Kirył. Jego rodzina poważnie podchodziła do spraw sukcesyjnych. Władimir Puryszkiewicz ${ }^{10}$ wspominal, że nigdy nie rozstawała się z myślą o ewentualnym odziedziczeniu tronu ". Prawa primogenituralne mieli także młodsi synowie Aleksandra II. W przeciwieństwie do apodyktycznego Siergieja i beztroskiego Aleksego najmłodszy Paweł założył zalegalizowaną prawnie rodzinę. Prawo dziedziczenia kończyło się na jego synu Dymitrze. Pozbawionymi szans byli Mikołajewiczowie, Michajłowiczowie i Konsantynowiczowie. Pierwsi wywodzili się od syna Mikołaja I, Mikołaja Mikołajewicza. Książę nie cieszył się zaufaniem Aleksandra II. Był dla niego źródłem niesubordynacji i defetyzmu armii rosyjskiej². Stosunki między braćmi stały się zarzewiem niechęci Mikołajewiczów do carów. W 1886 roku ich los podzielili potomkowie najmłodszego syna Mikołaja I, Michała. W przeciwieństwie do reszty Michajłowiczowie nie wykazywali zainteresowania koroną. Przyjęli rolę komentatorów rodowych. Świadczą o tym opublikowane wspomnienia Aleksandra Michajłowicza. Ich postawę podzielali wywodzący się od drugiego co do

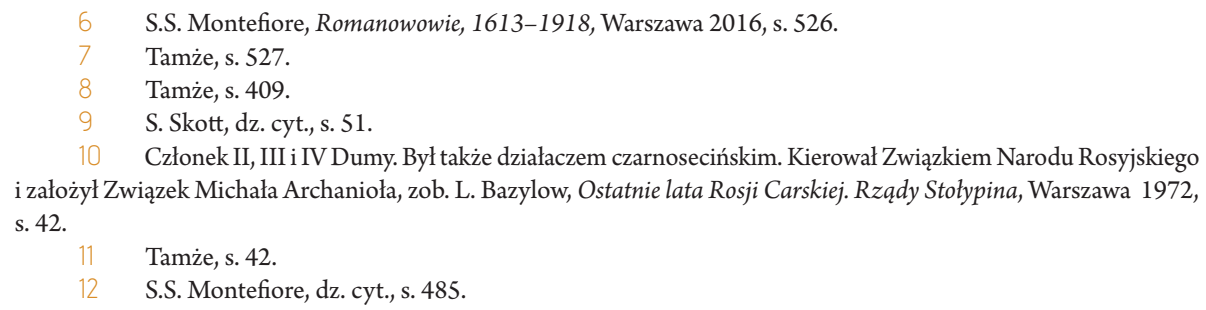


starszeństwa syna Mikołaja I, Konstantynowiczowie. Przez jego przykre doświadczenia polityczne dzieci odsunęły się od dworu. Najstarszy Konstanty Konstantynowicz poświęcił się poezji i muzyce.

W czasach Mikołaja II Aleksander Michajłowicz dokonał chłodnej kalkulacji stosunków rodzinnych. Stwierdził, że śmierć Aleksandra III przyśpieszyła wybuch rewolucji o ćwierć wieku' ${ }^{13}$. Dodał, że zapoczątkowała też nowy etap walki o władzę ${ }^{14}$. Obok „adeptów rewolucyjnego podziemia” do wyścigu o nią dołączyli krewni cara. W przeciwieństwie do ojca, Mikołaj II nie umiał zdyscyplinować rodziny. Ludwik Bazylow stwierdził, że największy wpływ na niego miało trzech stryjów ${ }^{16}$. Razem z Mikołajem Mikołajewiczem (młodszym) do carskiego gabinetu często przychodzili Siergiej i Władimir Aleksandrowiczowie. Siłą antagonistyczną była również małżonka cara, Aleksandra Fiodorowna. Simon Sebag Montefiore opisał ją jako poważną, pełną zahamowań, nerwową angielską damę $e^{17}$ Cechował ją charakterystyczny dla wnuczek królowej Wiktorii upór i zarozumiałość. Największą wadą był zupełny brak zrozumienia ludzi. Brat, Ernest z Hesji, stwierdził, że potrzebowała: „człowieka o silniejszej woli, który mógłby nad nią dominować i wziąć ją w karby”" . Mikołaj II z pewnością takim typem osobowości nie był. Carską parę skonfliktowały z rodziną sprawy matrymonialne. Wielcy książęta zawierali morganatyczne małżeństwa wbrew Cerkwi i carowi. Przykładem był ślub Kiryła Władimirowicza z rozwiedzioną z bratem carycy Wiktorią Melitą Koburg. Po matrymonialnych incydentach Mikołaj II nakazywał opuszczać nieposłusznym krewnym Rosję. Obok obyczajowości drugim problemem była hemofilia carewicza Aleksego, przez którą małżonkowie wycofali się z życia publicznego. Próba wyleczenia choroby doprowadziła do pojawienia się na dworze Grigorija Rasputina. Jego obecność stała się powodem ostatecznego zwaśnienia rodziny.

Pochodzący z chłopskiego rodu Rasputin ingerował w sprawy dynastyczne. Przykładem jest niedopuszczenie do ślubu księżnej Olgi Mikołajewnej z Dymitrem Pawłowiczem. Mikołaj Mikołajewicz kazał imperatorowi usunąć starca ${ }^{19}$. W trakcie pierwszej wojny światowej Rasputin zaczął przeszkadzać także rosyjskim sojusznikom. Głosił poglądy o charakterze pacyfistycznym, przez co zginął w zainspirowanym przez

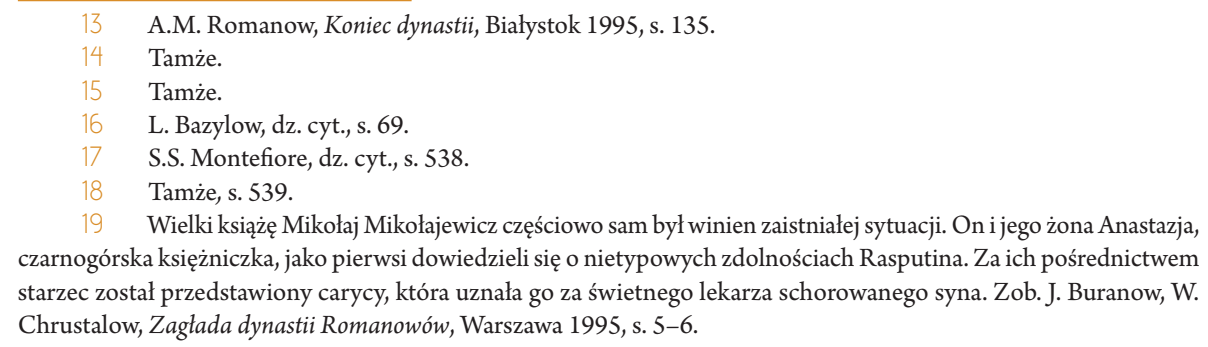
czarnogórska księżniczka, jako pierwsi dowiedzieli się o nietypowych zdolnościach Rasputina. Za ich pośrednictwem starzec został przedstawiony carycy, która uznała go za świetnego lekarza schorowanego syna. Zob. J. Buranow, W. Chrustalow, Zagłada dynastii Romanowów, Warszawa 1995, s. 5-6. 
angielską agenturę spisku. Morderstwo podzieliło ród, który w większości bronił uczestniczącego w zabójstwie Dymitra Pawłowicza i spowinowaconego Feliksa Jusopowa. Przejawem niechęci do Mikołaja i Aleksandry był zawiązany pod koniec 1916 roku spisek wielkich książąt. Według francuskiego ambasadora Maurice’a Paléologue’a był dziełem Mikołaja Mikołajewicza oraz Kiryła, Borysa i Andrieja Władimirowiczów. W wyniku przewrotu pałacowego krewni chcieli zmusić cara do abdykacji i zamknąć Aleksandrę w klasztorze. Do osiągnięcia przez Aleksego dojrzałości regentem miał być Mikołaj Mikołajewicz. Rolę przywódcy wyznaczono Dymitrowi. Krewni uznali go za naznaczonego przez los konspiratora ${ }^{20}$. Kirył i Andriej prosili, by: „w żadnym wypadku nie ustawał w swych staraniach na rzecz zbawienia narodowego" ${ }^{21}$. Dręczony wyrzutami sumienia książę odmówil jednak podniesienia ręki na cesarza. Powiedział: „Nie złamię swojej przysięgi na wierność”2 . Problemem była też zsyłka Mikołaja Mikołajewicza na Kaukaz. Na wygnaniu w Persji znalazł się także Dymitr. Według dziennika Andrieja winną klęski była żona nieżyjącego Konstantego Konstantynowicza, Elżbieta Mawrikijewna. Dzięki niej caryca przechwyciła dokumenty, z których wynikało, że Mikołaj Mikołajewicz zamierzał przejąć tron ${ }^{23}$. Spisek został ujawniony przez zdradę. Mikołaj natomiast abdykował kilka miesięcy później na skutek rewolucji lutowej. Tron odziedziczył Michał Aleksandrowicz, jednak brat nie chciał być carem, ale też nie chciał zrzekać się tytułu. Książę oznajmił, że: „może przyjąć koronę jedynie od demokratycznie wybranego Zgromadzenia Konstytucyjnego" ${ }^{24}$. Uzależnił od niego sprawę swej abdykacji. Do tego czasu władzę w Rosji miał sprawować powstały w marcu Rząd Tymczasowy. Posunięcie miało pozbawić praw sukcesji czekającego w Finlandii na rozwój wydarzeń Kiryła. Książę był w rodzinnej niełasce, ponieważ w pierwszych dniach rewolucji lutowej przeszedł na stronę rozwiązanej przez cara Dumy z czerwoną kokardą na piersi. Zaoferował także usługi przewodniczącemu Dumy Michałowi Rodziance. Nikt z krewnych nie wybaczył mu zdrady. W przypadku tradycyjnego zrzeczenia się przez Michała tytułu, stałby się carem. Na warunkach kuzyna nie mógł nawet wysuwać roszczeń ${ }^{25}$. Rządy Michała trwały dzień. Rewolucja bolszewicka pozbawiła życia jego, Mikołaja z rodziną i krewnych z gałęzi Michajłowiczów, Konstantynowiczów oraz Pawłowiczów. Na wieść o niepokojach w Rosji państwa sojusznicze przybyły z interwencją wojskową. Romanowowie, którzy uniknęli rewolucyjnego wymiaru sprawiedliwości, schronili

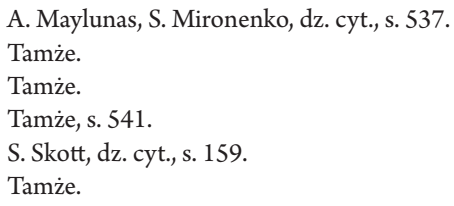


się na Krymie. Tam stali się zakładnikami sewastopolskiego sowietu. Aleksander Michajłowicz wspominał, że jego życie nie raz było zagrożone: „Obudziłem się nagle, ponieważ poczułem na czole dotknięcie czegoś zimnego. Podniosłem rękę, ale szorstki głos odezwał się nade mną z groźbą: Nie ruszać się, bo zastrzelę na miejscu!"26. W trakcie rewolucji Romanowowie stanowili kartę przetargową dla bolszewików. Wyklęty przez cara Dymitr Pawłowicz pierwszy podjął się politycznej aktywizacji. Według doniesień lokalnych gazet radzieckich udzielał się w Związku Działaczy Społecznych Michała Rodzianki. Jego członkowie byli legitymistami i uważali, że jedynym ratunkiem dla Rosji była restauracja monarchii ${ }^{27}$. Książę dowodził oddziałem białogwardzistów i Anglików. Prasa radziecka pisała, że zachodni sojusznicy podzielali poglądy organizacji i planowali osadzić Dymitra na tronie ${ }^{28}$. Paradoksalnie książę był też popularny wśród bolszewików. Z racji udziału w morderstwie uznali go za jedynego godnego zaufania Romanowa. Perspektywę współpracy z komunistycznym rządem uznał jednak za hańbiącą. Od tego czasu wszelkie wzmianki o jego antykomunistycznej działalności stały się elementem indoktrynacji mas ludowych ${ }^{29}$. Często używano ich jako usprawiedliwienia dla zbrodni dokonanych na Romanowach ${ }^{30}$. W 1919 roku Romanowowie opuścili Krym na przysłanym przez Jerzego V okręcie wojskowym Marlborough. Wzięli udział w Białej Emigracji, która zaczęła się w 1917 i trwała do 1923 roku. Była procesem masowego wychodźstwa rosyjskiej arystokracji, inteligencji i sfer wojskowych. Jej siłą napędową była sytuacja strategiczna Białej Armii. Proces opuszczania przez białogwardzistów państwa sprzyjał uchodźstwu cywilów. Głównymi ośrodkami emigracji był Półwysep Krymski, południowe krańce upadłego imperium oraz strefa położonego na dalekim wschodzie Primorya.

Na obczyźnie Aleksander Michajłowicz Romanow nagłaśniał problemy Rosji. Otrzymując w Sewastopolu osobny dla siebie krążownik „Forsythe” od admirała Calthorpe’a, popłynął na paryską konferencję pokojową. Pokładał nadzieję we Francji, jednak przewodniczący zjazdowi Georges Clemenceau wykazywał wstrzemięźliwość wobec Rosji. Według księcia francuski premier nie zawracał sobie głowy Europą Wschodnią. W trakcie każdej wzmianki o niej ignorancko odchylał się na oparcie fotela i zamykał oczy ${ }^{31}$. Jedyną osobą, która zdawała sobie sprawę ze znaczenia rewolucji bolszewickiej, był Winston Churchill. 14 lutego 1919 roku wygłosił mowę na rzecz interwencji militarnej w Rosji. Mimo to delegacja Wielkiej Brytanii podporządkowała się wytycznym Arthura Balfoura i Lloyda George’a, którzy uważali, że w chwili wybuchu

A.M. Romanow, Byłem Wielkim Księciem..., dz. cyt., s. 212.

J. Buranow, W. Chrustalow, dz. cyt., s. 228.

Tamże.

Tamże, s. 229.

Tamże.

A.M. Romanow, Bytem Wielkim Księciem ..., dz. cyt., s. 227. 
rewolucji Rosja przestała być sojusznikiem ententy. W pojęciu angielskiego gabinetu bolszewizm był reformą państwową. Warto także podkreślić, że obu Brytyjczyków miało nikłe pojęcie o Europie Wschodniej. Dowodem jest utożsamienie przez Llyoda George’a miasta Charków z nieistniejącym generałem Charkowem. Równie małą wiedzą wykazywała się delegacja amerykańska. Szczery do bólu Romanow opisał ją jako bardzo niedoświadczoną i niezręczną ${ }^{32}$. Prezydent Wilson uważał sprawę rewolucji bolszewickiej za rozległy w czasie proces decyzyjny. W rzeczywistości opieszałość i abstynencja Zachodu była wynikiem kolonialnych aspiracji nieżyjącego Disraeliego, 1. hr. Beaconsfielda. Mające wielki wplyw na ministerstwo spraw zagranicznych koncerny Royal Dutch i Henry Deterding planowały podzielić obszar upadłego imperium między ententę i państwa partnerskie ${ }^{33}$. Książę Aleksander przekonał się, że powrót do domu będzie niebywale trudny. Jego zdania nie podzielała Biała Emigracja, która postrzegała rewolucję bolszewicką jako tymczasowy stan niepokoju w państwie. Według Staffana Skotta Rosjanie przebywający we Francji czekali na upadek rządu bolszewickiego i szybką reemigrację ${ }^{34}$. Aleksander Michajłowicz właśnie tę postawę uznał za źródło wszelkich nieszczęść. Jego zdaniem cywilna część arystokracji nie uczyniła nic na rzecz swojej ojczyzny ${ }^{35}$. Jej bierność uważał za jedną z głównych przyczyn rewolucji i upadku imperium carskiego ${ }^{36}$. Ulubionymi miejscami migracji byly Nowy Jork, Mandżuria, Kalifornia, Paryż i Berlin. Na początku lat dwudziestych stolica Republiki Weimarskiej była najpopularniejsza wśród artystów i literatów. W Charlottenburgu i na przedmieściach Berlina mieszkało pół miliona Rosjan ${ }^{37}$. Popularność północnowschodnich Niemiec była wynikiem słabej kondycji ekonomicznej. Słabośći dewaluacja marki sprawiły, że Berlin był tanim miastem. Dla utrzymujących się ze sprzedaży rodzinnych kosztowności i dewiz Rosjan nie było problemu z wynajmem mieszkania ${ }^{38}$. Reformy gospodarcze rządu niemieckiego ustabilizowały walutę i zwiększyły koszty życia. Wielu Rosjan przeniosło się do Stanów Zjednoczonych lub Paryża, który uchodził za centrum intryg politycznych. Akceptacja przez świat nowej formy państwa rosyjskiego rozwiała wizję szybkiej repatriacji. Wśród emigrantów szerzyły się ruchy polityczne. Do 1923 roku miały podłoże monarchistyczne i konstytucyjne. Przejawem żywotności tych nurtów były emigracyjne stowarzyszenia. Pierwszym była skupiająca działaczy rewolucji lutowej „Mała Rosja”. Popularny był również powołany przez

Tamże, s. 224.

Tamże, s. 229-230.

S. Skott, dz. cyt., s. 254.

Tamże, s. 255.

Tamże.

O. Figes, dz. cyt., s. 525.

Tamże. 
generała Wrangla w 1924 roku Rosyjski Związek Ogólnowojskowy. Tworzyli go byli carscy wojskowi o monarchistycznych poglądach. Mimo paramilitarnego charakteru nie odegrał znaczącej roli politycznej. Zajmował się ideologiczną walką z komunizmem.

Napływ literatów ze Związku Radzieckiego zmodyfikował podstawę ideologiczną legitymistów. Zdarzały się sytuacje, w których inteligencja Białej Emigracji zasiadała przy jednym stole z przedstawicielami lewicowej awangardy ${ }^{39}$. Doprowadziło to do zatarcia granicy między kulturą emigracyjną a sowiecką i powstania idei jedności narodowej ${ }^{40}$. Pod wpływem zwolenników unifikacji obyczajowości doszło do ewolucji rosyjskiego monarchizmu. Jego przejawem był ruch młodzieżowy zwany „Rosyjską Wiosną”.W tym czasie Romanowowie walczyli z osobistą pauperyzacją. Przekazy o wywiezieniu przez nich wielkiej fortuny rodowej bliższe są fikcji niż prawdzie. Rozrzucone po świecie carskie miliony byly wytworem wyobraźni europejskich dziennikarzy. W latach dwudziestych w gazetach często widniały nagłówki typu: „Angielski Bank Państwowy przechowuje ogromny majątek dynastii Romanowów”" ${ }^{\text {"1 }}$. Aleksander Michajłowicz zaprzeczał tym twierdzeniom. Według niego składowane od czasów Aleksandra II 20 milionów funtów szterlingów w Banku Londyńskim zainwestowano w szpitale i filantropie ${ }^{42}$. Fakt ten długo nie ujrzał światła dziennego, ponieważ żaden z carów nie miał w zwyczaju podawać do publicznej wiadomości dowodów dobroczynności. Życie na poziomie przeciętnego Europejczyka okazało się trudniejsze dla damskiej części rodu. Księżne odebrały typowo dworskie wykształcenie, które nie ułatwiło im egzystencji w okcydentalnej części świata. Nie orientowały się w cenach artykułów żywnościowych i nie potrafily przeprowadzić prostej operacji kupna biletu na pociąg. Początkowo ich źródłem utrzymania byly rodzinne kosztowności. Sprzedaży precjozów i klejnotów często towarzyszyło oszustwo ze strony jubilerów, którzy celowo oferowali zaniżone ceny ${ }^{43}$. Nawet wielka księżna Ksenia, pomimo mieszkania razem z matką u duńskich krewnych, po jej śmierci sprzedała jedyne źródło utrzymania - szkatułę $\mathrm{z}$ biżuterią. $\mathrm{W}$ ten sposób słynna spuścizna Romanowów została rozprzedana za przysłowiowy bezcen. Należy wspomnieć, że swój udział mieli w tym także Windsorowie. Angielscy jubilerzy wycenili kolekcję Marii Fiodorowny na 350 tysięcy funtów ${ }^{44}$. Czerpiący zyski z transakcji krewni wypłacili córkom carycy jedynie $36624^{45}$.

Tamże, s. 526.

Tamże.

A.M. Romanow, Bytem Wielkim Księciem ..., dz. cyt., s. 116.

Tamże.

S. Skott, dz. cyt., s. 136.

Co się stało z bezcennymi klejnotami rosyjskich carów?, http://www.newsweek.pl/wiedza/historia/ bezcenne- klejnoty-rosyjskich-carow,artykuly,357311,1.html [dostęp: 22.09.2017].

Tamże. 
Nigdy nie stworzono listy zawierającej wykaz zbytych kosztowności. Członkowie rodziny królewskiej do dziś nie potrafią stwierdzić, kto je nabył. Konsekwencją determinacji Romanowów i bezmyślności Windsorów jest rozproszenie rosyjskiej biżuterii i precjozów po całym świecie. Do dziś są znajdowane na giełdach staroci i w amerykańskich lombardach. Księżne przeznaczały pieniądze na kursy dokształcające, jak krawiectwo i fotografia. Przykładem jest jedna z kuzynek Mikołaja II, Maria Pawłowna. Wspominała, że po rewolucji bolszewickiej jej rodzina stała się zbiorem niepotrzebnych jednostek, którym blisko było do statusu wyrzutków ${ }^{46}$. Spróbowała swoich sił w świecie kapitalizmu. Przy wsparciu Gabriel Chanel założyła paryski Dom Haftów Rosyjskich „Kitmir” ${ }^{\text {” }}$. Dzięki księżnej w całej Francji rosyjskie arystokratki zajęły się szyciem ${ }^{48}$. Czas współpracy z białymi emigrantami projektantka nazwała rosyjskim okresem. Firma dostarczała jej ekstrawaganckich materiałów i słowiańskich motywów kulturowych.

Współpraca z Rosjanami nadała pędu karierze projektantki. Osobą, która przyczyniła się do jej sukcesów, był brat Marii Pawłowny, Dymitr. Znał Coco Chanel od 1914 roku. W 1920 roku ich relacje przekształcily się w romans. W jego trakcie Chanel szukała kogoś, kto pomógłby jej rozwinąć przemysł perfumeryjny. Według biografa projektantki, Paula Moranda, książę zainicjował spotkanie z carskim perfumiarzem Ernestem Beaux. Z wywiezionej przez niego rosyjskiej wody toaletowej Rallet $\mathrm{N}^{\circ} 1$ Chanel uczyniła jedne z najsłynniejszych perfum na świecie - Chanel $N^{\circ} 5$. Niedysponujący dużymi pieniędzmi Dymitr starał się być źródłem inspiracji dla kochanki. Podarował jej długi sznur pereł swojej matki. Coco skopiowała go i wprowadziła na rynek jako nowy trend $\mathrm{w}$ modzie ${ }^{49}$. Po zakończeniu romansu nazwała nawet wyprodukowaną przez swój koncern szminkę o kolorze krwistej czerwieni imieniem księcia. Mimo rozstania pozostali przyjaciółmi. W latach trzydziestych Romanow znowu zaaranżował biznesowe spotkanie z amerykańskim biznesmenem. Według artykułu w „Collier’s” z 1932 roku: „wielki książę Dymitr z Romanowów mimochodem przedstawił Samuela Goldwyna z branży filmowej [Mademoiselle] Gabriele Chanel" ${ }^{\text {}}$. W wyniku rozmowy pełnej komplementów projektantka podpisała wart milion dolarów kontrakt na zaprojektowanie strojów w Hollywood ${ }^{51}$.

\footnotetext{
S. Skott, dz. cyt., s. 186.

47 T.J. Mazzeo, Sekretne życie Chanel N5. Pierwsza biografia najstynniejszych perfum świata, Kraków 2016, s. 76.

Tamże, s. 72 .

A. Madsen, Chanel. Kobieta nieuchwytna, Warszawa 1994, s. 118.

T.J. Mazzeo, dz. cyt., s. 166.

Tamże.
} 
Osławiona na całym świecie Francuzka dobrze poznała męską część carskiej familii. Po rozstaniu z Dymitrem powiedziała: „Ci wielcy książęta wszyscy byli tacy sami. Wyglądali wspaniale, ale za tym nie kryło się nic. Zielonoocy, o pięknych rękach i ramionach, lubiący spokój, lękliwi. Pili dużo, żeby zabić strach..." ${ }^{52}$.Źródłem lęku była konfrontacja z brutalną rzeczywistością. Po przyjeździe do zachodniej Europy Romanowowie podzielali nadzieję Białych Emigrantów na szybki powrót do domu. Pogląd ten dobrze oddają wspomnienia Marii Pawłownej: „przeszłość, nasza przeszłość, wciąż stanowiła kluczową część naszego życia: byliśmy jak ludzie gwałtownie wyrwani z przyjemnego snu, czekający na chwilę, kiedy na powrót zasną i podejmą przerwany wątek" ${ }^{53}$. Tkwiąc w sentymentalnej złudzie, męskie grono dynastii powróciło do spraw sukcesji. Według Petera Kurtha chętnych do nieistniejącego tronu było wielu ${ }^{54}$. W monarchistycznych środowiskach Białej Emigracji Mikołaj Mikołajewicz był najlepszym kandydatem na głowę rodu i cara. Oczekiwano od niego objęcia dowództwa nad rosyjską społecznością. Jednak stary książę popadł w polityczną abstynencję. Torpedował propozycje i roszczenia krewnych do tytułu. Zadowolił się przywództwem nad Rosyjskim Związkiem Ogólnowojskowym. Funkcję tę piastował do śmierci w 1929 roku. W tej sytuacji mile widziany w roli cara na uchodźstwie był Dymitr Pawłowicz. Na drugim miejscu był ambitny Kirył Władimirowicz, lecz jego kandydatury nie tolerowali krewni. Z czasem sytuacja przybrała groteskową formę. W rosyjskich restauracjach stawiano pieniądze na kandydatów. Pogrążający się w depresji Dymitr nie zabiegał o tytuły. W obliczu jego bezczynności Kirył ogłosił się w 1922 roku carem i głową rodu. Dwa lata później posunął się dalej, przyznając sobie tytuł Autokraty Rosji. Za swego następcę uznał urodzonego w 1917 roku syna Władimira.

Widząc stosunek świata do ZSRR, Romanowowie popadli we wspomniany przez Chanel lęk. Kirył zdawał sobie sprawę, że szanse na repatriacje przybrały formę sentymentalnego widma. Zrozumiał, że warunkiem prawnej egzystencji była działalność polityczna. Przeświadczenie przejął Władimir Kiryłowicz, który po śmierci ojca w 1938 roku wydał memoriał. W nocie zwrócił się „do wszystkich Rosjan, którym drogi jest los Rosji” ${ }^{5}$. Było to wezwanie zachęcające Białych Emigrantów do skupienia się wokół jego osoby.

Romanowowie wciąż przedstawiali wartość polityczną dla ruchu, który przeszedł do historii jako „Rosyjska Wiosna”. Jej wypustem była paramilitarno-legitymistyczna organizacja zwana Związkiem Młodej Rosji. Powstała w 1923 roku w Monachium

A. Madsen, dz. cyt., s. 125.

Tamże, s. 76.

P. Kurth, Anastazja, Warszawa 1993, s. 120.

S. Skott, dz. cyt., s. 278. 
z inicjatywy zrusyfikowanego szlachcica perskiego Aleksandra Lwowicza Kazem-Beka, który dwa lata później zmienił jej nazwę na Związek Młodorosjan. Stowarzyszenie miało charakter synkretyczny. Łączyło idee ortodoksji, samodzierżawia, stalinizmu, faszyzmu, socjalizmu i rosyjskiego nacjonalizmu ${ }^{56}$. W rzeczywistości odzwierciedlało myśl polityczną Kazem-Beka i Dymitra Gordeńskiego. Według Młodorosjan przyczyną upadku Imperium Rosyjskiego była zmurszałość reżimu. Za głównego winowajcę zepsucia uważali burżuazję. W ich przekonaniu bolszewizm był negatywnym skutkiem jej działalności. Synkretyzm poglądowy zrodził ideologię „sowieckiego cara” ${ }^{57}$. Tylko jego powrót mógł uratować Rosję, jednak jako władca miał różnić się od poprzedników. Dla stowarzyszenia źródłem jego władzy była wolna wola chłopstwa, robotników i rad żołnierskich ${ }^{58}$. Naturalnym ograniczeniem miały być instytucje sowieckie. Zatrzymanie radzieckich form ustrojowych było wynikiem fascynacji Kazem-Beka osobą Stalina.

Akces do organizacji jako przyszły car zgłosił Władimir. By zbliżyć się do klasy robotniczej, podjął półroczną pracę w angielskiej fabryce maszyn ${ }^{59}$. Zgodnie z zasadą samodzierżawia nie mógł jednak należeć do żadnego ugrupowania politycznego. Na jego prośbę do Związku Młodorosjan dołączył popularny Dymitr Pawłowicz. Wymęczony gruźlicą książę ograniczył się do przemówień publicznych i nadzorowania zajęć sportowych. Kariera obu Romanowów w organizacji nie była długa.

Na początku lat czterdziestych Kazem-Bek nawiązał kontakty z NKWD. Związek stawał się coraz bardziej zinfiltrowany przez radziecką agenturę. Obecność Romanowów przykuła uwagę Adolfa Hitlera. Führer miał nadzieję, że Dymitr Pawłowicz zgodzi się objąć dowództwo nad organizacją i wyruszyć z armią Wehrmachtu na Związek Radziecki. Książę odmówił ze względu na pogardę wobec Hitlera i słabe zdrowie. Przejawem nienawiści było wystąpienie publiczne, w którym oszkalował nazistowskiego przywódcę.

Związek Młodorosjan zaprzestał działalności po zajęciu przez Niemcy Francji. Władimira uważano za trzon rosyjskiej emigracji. Wykorzystał to Hitler, który chciał wykorzystać Romanowa w celach propagandowych. Oczekiwał wydania manifestu zachęcającego Rosjan z francuskiego ruchu oporu do współpracy z Niemcami. Władimir odrzucił propozycję, przez co trafił do obozu koncentracyjnego w Compiègne. Końca wojny doczekał w Austrii. W podobnej sytuacji znalazła się również jego siostra Kira. Razem z mężem Ludwikiem Ferdynandem Hohenzollernem poświęciła się agitacji antynazistowskiej, za co ścigało ich gestapo.

\footnotetext{
mladorossov-kazem-beka [dostęp: 8.09.2017].

Tamże.

Tamże.

S. Skott, dz. cyt., s. 276.
}

Русская весна - преемники младороссов Казем-бека, http://poistine.org/russkaya-vesna-preemniki- 
Lata 1939-1945 były dla Romanowów bardzo trudne. Jednak nawet perspektywa utraty krewnych nie wyeliminowała rodzinnych problemów. Przerażona nową rzeczywistością rodzina nie sprzeciwiała się czynnie Kiryłowi Władimirowiczowi w latach dwudziestych. Po jego śmierci zgodnie z prawem dynastycznym obowiązującym w Wielkiej Brytanii, Szwecji, Danii czy Belgii prawowitym następcą był Władimir ${ }^{60}$. Mawial, że: „Tronu nie wolno porzucić na pastwę losu, wszyscy muszą wiedzieć, że nie jest on pusty" ${ }^{\prime \prime}$. Żyjąc w przeświadczeniu pierwszeństwa, wydał w 1969 roku manifest, w którym zawczasu uznał córkę Marię za dziedziczkę rosyjskiego tronu. Memoriał naruszył zasadę patrylinearności. Krewni zaakceptowaliby decyzję, gdyby manifest nie naruszyl ich praw rodowych. Nieformalny car zapowiedzial pozbawienie nazwiska wszystkich, którzy zawarli morganatyczne małżeństwa. Według memoriału mieli posługiwać się godnością „Romankowski”.

Sprzeciw złożyli członkowie z gałęzi Konstantynowiczów, Mikołajewiczów i Michajłowiczów. Na czele opozycji stał Roman Pietrowicz. Jako bratanek Mikołaja Mikołajewicza zyskał sobie w obrębie klanu wielu zwolenników. Miłujący wojskowe klimaty książę nie raz torpedował w obraźliwy sposób roszczenia Kiryła. Księcia Romana poparł prawnuk wygnanego przez Aleksandra III Konstantego Mikołajewicza, Wsiewołod Iwanowicz. Syn serbskiej księżniczki miał kompleks na tle pochodzeniowym. Po brutalnym zamordowaniu jego ojca przez bolszewików matka zabroniła księciu uczyć się rosyjskiego. Później Wsiewołod całe życie żałował, że nie władał tym językiem $^{62}$. Sprzeciw złożył razem z Andriejem Aleksandrowiczem. Śmiałość tego drugiego determinował ojciec. Zmarly w 1933 roku Aleksander Michajłowicz był jedyną osobą, której Kirył i Władimir nie ośmielili się drażnić.

Książęta wystosowali protest $\mathrm{w}$ formie pisma. Zarzuty co do gróźb Władimira argumentowali pochodzeniem jego żony. Leonida Bagration Mukhrani także nie legitymowała się odpowiednim pochodzeniem z uwagi na matkę Polkę, Helenę Sigismundową Nową-Złotnicką. Oskarżenie ujęli w jednym z punktów: „Żona księcia Władimira posiada taki sam status, jak żony wszystkich wielkich pozostałych książąt Rosyjskich i książąt cesarskiej krwi” ${ }^{63}$. Według trzeciego odnośnika: „Z tego powodu nie uznajemy jego córki Marii za wielką księżnę i uważamy mianowanie księżnej Marii Władimirowny przyszłą «Strażniczką Rosyjskiego Tronu» i «Głową Rosyjskiego Cesarskiego Rodu» za akt bezprawny i samowolny ${ }^{154}$.

Tamże.

Tamże, s. 281.

Tamże, s. 211.

Tamże, s. 284.

Tamże. 
Konflikt pogłębił siedem lat później Władimir. W 1976 roku przyznał mężowi Marii, Franciszkowi Wilhelmowi pruskiemu, tytuł wielkiego księcia rosyjskiego. Córka stała się jego następczynią „w celu utworzenia nowej dynastii HohenzollernRomanow" ${ }^{5}$. Krok Władimira doprowadził do ostatecznej scysji z klanem. Roman Pietrowicz nosił się z zamiarem założenia organizacji, która zrzeszyłaby rozproszonych po świecie krewnych. Wizję spełnił starszy syn Mikołaj Romanowicz. Zainspirował go pomysł odnaleziony w dokumentach ojca. Z Andriejem Aleksandrowiczem założył w 1979 roku Stowarzyszenie Rodziny Romanowów. Do dziś zrzesza wyklętych przez Władimira spadkobierców dynastii i udziela się na polu charytatywnofilantropijnym w Federacji Rosyjskiej. Jego członkowie nie uznają Władimirowiczów za główny pień rodu. Wedle rodzinnego porozumienia najmłodszy syn Aleksandra Michajłowicza, Wasilij Aleksandrowicz, stanął na czele rodziny w 1979 roku. Mikołajowi Romanowiczowi przypadła rola „siły napędowej” ${ }^{” 6}$. Próbował dojść do porozumienia z Władimirowiczami. Za idealny moment uznał zaliczenie przez rosyjską Cerkiew w Stanach Zjednoczonych zamordowanych Romanowów w poczet świętych. Spotkanie w Nowym Jorku nie ociepliło jednak relacji. Po przyjściu na świat w 1981 roku wnuka Władimira, Gieorgija Michajłowicza, rada familijna wystosowała kolejny protest. Dokument powtarzał zarzuty z 1969 roku: „Rada familijna Romanowów oświadcza niniejszym, że szczęśliwe narodziny potomka w pruskim domu królewskim nie dotyczą rodziny Romanowów, ponieważ nowo narodzony książę nie należy ani do Rosyjskiego Domu Cesarskiego, ani do rodu Romanowów ${ }^{207}$.

Rodzinna organizacja była sceptycznie nastawiona co do spadkobierstwa Władimirowiczów. Według starszeństwa po śmierci Władimira jego miejsce powinien zająć syn Dymitra Pawłowicza, Paul Romanow Ilyinski. Jednak podobnie jak ojciec nie wyrażał chęci zostania pretendentem. Powiedział: „Te tytuly nie należą do mnie i nie są mi potrzebne" ${ }^{n 8}$. Podobny stosunek wykazał Mikołaj Romanowicz. Po nieudanej próbie pogodzenia z Władimirem wyznał: „Na tronie Romanowów nikt nigdy nie zasiądzie. Ale gdyby w Rosji przywrócono monarchię, niech on tak wychowa wnuka, aby był najlepszym kandydatem. Wtedy założy nową dynastię. Nas to już nie interesuje. Pretendenci rzadko obejmują tron, do którego rościli pretensje, a po siedemdziesięciu latach - nigdy" ${ }^{m 9}$.

Wypowiedź księcia jest idealnym podsumowaniem dzisiejszej sytuacji społecznopolitycznej Romanowów. Po upadku ZSRR prawnuki Mikołaja I odnowily kontakt 
z Rosją. Klanowa organizacja i Władimirowiczowie udzielają się charytatywnie i utrzymują dobre relacje z Władimirem Putinem. Maria Władimirowna cieszy się dużą popularnością. Za tytularną następczynię tronu uznaje ją Kościół prawosławny i rosyjskie ugrupowania monarchistyczne, jak Wielka Rosja czy Rosyjski Ruch Imperialny. Nazywa siebie głową rodu, lecz nie akceptują tego opozycyjnie nastawieni krewni. Po śmierci Wasilija Aleksandrowicza funkcję przyznali bratu Mikołaja Romanowicza.

Zmarły w 2016 roku książę Dmitrij Romanowicz Romanoff dzięki działalności kulturowej i filantropijnej również cieszył się sympatią rosyjskiego rządu. Był brany pod uwagę jako potencjalny kandydat na cara, lecz bez poparcia instytucjonalnego. Książę podzielał zdanie brata i nie zabiegał o rolę tytularnego imperatora. W jednym z wywiadów przyznał, że bliżej mu było do duńskiego socjalizmu niż monarchizmu ${ }^{70}$. Jako poliglota i kosmopolita większą część życia spędził na stanowisku pośrednika w sprzedaży aut i kierownika międzynarodowego wydziału Duńskiego Banku Handlowego w Kopenhadze.

Podsumowując, w XIX wieku dynastyczną kością niezgody było poczucie niesprawiedliwości. Primogenitura Pawła I wywoływała zazdrość i zrodziła chorobliwą ambicję w braciach panującego. Przykładem są relacje księcia Władimira Aleksandrowicza z Aleksandrem III i stosunek jego synów do Mikołaja II. Nieumiejętność porozumienia się krewnych doprowadziła w 1916 roku do spisku, który miał na celu pozbawić cara władzy. Zamiary konspiratorów zrealizowała rewolucja lutowa. Następny przewrót pozbawił życia trzon dynastii, jak i reprezentantów jej odgałęzień.

Ocaleli Romanowowie wzięli udział w Białej Emigracji. W jej wyniku rozproszyli się po całym świecie. Niestety, trauma wywołana stratą bliskich nie zażegnała rodowych niesnasek. Problem wyłonienia głowy rodu i następcy nieistniejącego tronu w dalszym ciągu przyćmiewał perspektywę rodzinnego porozumienia. Dowodem tego jest fakt, że wielu Romanowów znalazło nowe priorytety w swoim życiu. Kobiety, nieposiadające pragmatycznego wykształcenia, skupiły się na zaspokajaniu podstawowych potrzeb. Próbowały swoich sił w handlu i typowo kapitalistycznych formach zarobku. Mężczyźni, wierząc w szybką repatriację, oddali się polityce.

Aktywizacja w Białej Emigracji nie przyniosła oczekiwanych skutków. Naraziła Romanowów na dodatkowe niebezpieczeństwo. Zagrożeniem była sowiecka agentura i siły nazistowskich Niemiec. Dla Hitlera byli narzędziem propagandy w walce ze Związkiem Radzieckim. Odmowa współpracy ściągnęła na ród groźbę przemocy ze strony nacjonalistycznych ugrupowań. Paradoksalnie, nawet pobyt Władimira 
Kiryłowicza w obozie koncentracyjnym nie pomógł przedłożyć więzów rodzinnych nad ambicję przodków.

Relacje Romanowów po drugiej wojnie światowej to idealny przykład pychy i ucieczki od rzeczywistości. Władimirowiczowie wykazywali się wysoką świadomością pochodzenia. Prawdopodobnie gdyby Władimir nie wywołał przysłowiowej burzy manifestem z 1969 roku, Romanowowie z gałęzi Konstantynowiczów, Mikołajewiczów i Machjłowiczów nie odświeżyliby relacji. Groźba utraty nazwiska i sprzeciw wobec matrymonializmu krewniaka przyśpieszyły powstanie Stowarzyszenia Rodziny Romanowów. Oczywiście, nie należy go uznawać jedynie za przejaw opozycyjności. Organizacja byla także przejawem szlachetności Romana Pietrowicza, który wcześniej chciał zjednoczyć rodzinę.

Przed 1991 rokiem wielu Romanowów miało trudności z określeniem swojej przynależności narodowej. Ostentacyjne obnoszenie się z prozelityzmem i republikanizmem mogło być wynikiem politycznej abstynencji, która miała chronić ich od radzieckiej agentury. Tylko Władimirowiczowie pokazywali negatywny stosunek do ZSRR. Mikołaj Romanowicz podczas wywiadu nie wiedział, którą stronę świata uznać za ojczyznę. Dopiero jego brat nawiązał łączność z krajem przodków. Kontakty Władimira Putina z Marią Władimirowną i zmarłym już Dmitrijem Romanowiczem są wynikiem działań obu stron. Potomkowie carów uczyli się w dzieciństwie historii kraju przodków i często przelewali ją na papier. Dziś przekazują nawet pamiątki swoich rodziców do rosyjskich muzeów. W samej Rosji dokonały się wielkie zmiany w zakresie nauczania przedmiotów humanistycznych. Pozytywnej metamorfozie uległ sposób postrzegania carów i ich roli w rosyjskim społeczeństwie. W centrum zainteresowania znaleźli się również ich krewni. Coraz częściej dostrzega się ich wpływ i wkład finansowy w rozwój rosyjskiej kultury. Dzięki zmianom na tle mentalnościowym i naukowym Romanowów zaczęto uważać za niekoniecznie złą i uwsteczniającą część narodowej historii. 


\section{BIBLIOGRAFIA}

Andrusiewicz A., Romanowowie. Imperium i familia, Kraków 2014;

Bazylow L., Ostatnie lata Rosji carskiej. Rządy Stolypina, Warszawa 1972;

Buranow J., Chrustalow W., Zagłada dynastii Romanowów, Warszawa 1995;

Co się stało z bezcennymi klejnotami rosyjskich carów?, http://www.newsweek. $\mathrm{pl} /$ wiedza/historia/bezcenne- klejnoty-rosyjskich-carow,artykuly,357311,1.html [dostęp: 22.09.2017];

Figes O., Taniec Nataszy. Z dziejów kultury rosyjskiej, Warszawa 2011;

Kurth P., Anastazja, Warszawa 1993;

Madsen A., Chanel. Kobieta nieuchwytna, Warszawa 1994;

Maylunas A., Mironenko S., Mikołaj II i Aleksandra: nieznana korespondencja, Warszawa 1998;

Mazzeo T.J., Sekretne życie Chanel $N^{\circ}$ 5. Pierwsza biografia najstynniejszych perfum świata, Kraków 2016;

Montefiore S.S., Romanowowie, 1613-1918, Warszawa 2016;

Русская весна - преемники младороссов Казем-бека, http://poistine.org/russkaya-vesna-preemniki-mladorossov-kazem-beka [dostęp: 8.09.2017];

Romanow A.M., Byłem Wielkim Księciem (koniec dynastii), Białystok 2004;

Romanow A.M., Koniec dynastii, Białystok 1995;

Skott S., Romanowowie wczoraj i dziś, Warszawa 2004. 